ARTICLE

https://doi.org/10.1057/s41599-018-0199-0

\title{
A new sustainability model for measuring changes in power and access in global commodity chains: through a smallholder lens
}

\author{
Benjamin Neimark', Sarah Osterhoudt ${ }^{2}$, Hayley Alter $^{1} \&$ Adrian Gradinar ${ }^{1}$
}

\begin{abstract}
High-value agricultural commodities face substantial economic, environmental and social sustainability challenges. As a result, commodity industries are adopting sustainable supply- and value-chain models to make production more efficient, traceable and risk-averse. These top-down models often focus on giving higher prices to smallholder producers. While an important component of sustainability, this focus on farm-gate prices has shown mixed results in part because they are less effective in highlighting the asymmetrical power relationships and the socio-economic and ecological complexity in high-value commodity production. Here, we use a novel method to measure and visualise changes in smallholder power in Madagascar's northeast 'vanilla triangle'-home to about $80 \%$ of the world's high quality vanilla. Our results reveal the paradox that during the recent price surge an overall increase in smallholders' multi-dimensional power to access economic benefits was accompanied by a decrease in many other equally important measures of sustainability. This illustrates how effective models for understanding global sustainable commodity chains should incorporate smallholders' perspectives that often emphasise complexity and uncertainty, and which aims to increase power and access for producers across both high and low price points.
\end{abstract}

\footnotetext{
${ }^{1}$ Lancaster University, Lancaster, UK. ${ }^{2}$ Indiana University, Bloomington, IN, USA. Correspondence and requests for materials should be addressed to B.N. (email: b.neimark@lancaster.ac.uk)
} 


\section{Measuring and visualising changes to smallholder power}

ocial, economic and environmental sustainability standards are increasingly mainstream in the production of high-value agricultural commodities such as coffee (Mutersbaugh, 2002), cacao (Clough et al., 2009), acai (Brondízio et al., 2002), palm oil (Paoli, 2015) and vanilla (Osterhoudt, 2017). However, there is a growing recognition that mainstream sustainability models often struggle to achieve their objectives (Newton et al., 2013; Lambin et al., 2018; Thorlakson et al., 2018). This may include widespread failings for the millions of smallholder producers who are often purported to be the beneficiaries of sustainability initiatives (Lee et al., 2012).

These failings are frequently attributed to less-recognised asymmetrical power relations along the commodity chain, from smallholder producers to multinational suppliers (Abdulsamad et al., 2015). Power issues-including structural inequalities and social relations between market actors-are a recurrent and key conceptual dimension for understanding sustainability outcomes in commodity studies (Dallas et al., 2017). However, power is often treated as a 'black box': generic, under-described and certainly unmeasured.

In this study, we propose a novel way of exploring how smallholders experience commodity production and the various dimensions of sustainability-environmental, social and economic. In particular, we make power an explicit and visible part of our analysis, mapping smallholders' ability to access the monetary and non-monetary benefits from high-value commodities under dynamic environmental, social and economic conditions. We draw on Ribot and Peluso's 'access mapping' approach to tracing benefits in high-value commodities (Ribot and Peluso, 2003). Similarly, we adopt an actor-orientated approach to power, which recognises an individual's agency in accessing certain benefits and resources. We situate this agency within historically, culturally and politically produced social structures (Weber, 1978; Foucault, 1991; Watts, 1993; Ribot and Peluso, 2003; see section below for more on our approach to power).

Our focus, however, moves beyond conceptualising power, providing a unique applied model that both measures and visualises changes to smallholder power as a lens for assessing sustainability. This approach is attractive for its analytic ability, which begins with smallholder perspectives on various multidimensional factors (e.g., new technologies, security and customary land tenure) that affect sustainability in diverse ways. We make these variables explicit and highly adaptable to other commodities so that future sustainability initiatives can do more to recognise their role and dynamism.

Vanilla production provides an excellent example to study the relationship between commodities, sustainability and smallholder power. Similar to many high-value global commodities, such as palm oil and cacao, it primarily relies on poor, smallholder farmers for production. Moreover, it has been the focus of both sustainability initiatives (Foster, 2013) and price spikes; in April 2017, a kilogram of high quality Vanilla planifolia reached approximately $\$ 600$, representing a 14 -fold price increase since 2013 (Terazono, 2017). The paradox is that prices are frequently promoted in mainstream sustainability initiatives. Price increases may present income opportunities for upstream market actors, such as smallholders, intermediaries and regional exporters. However, they also pose complex challenges for the vanilla market and economic, social and environmental sustainability. The focus on price comes at the cost of ignoring power in these contexts, thereby reducing our ability to capture a comprehensive understanding of smallholders' experiences, particularly in periods of rapid price fluctuations, and socio-economic and environmental change.
For instance, the recent high vanilla prices in Madagascar have driven increases in early harvests of unripe 'green' pods, thereby diminishing product quality. Smallholders are also foregoing vital food crops desperately needed to make it through the hunger season'-the lean period when food is scarce before the rice harvest (Laney and Turner, 2015)_further fuelling speculation and the clearing of some of the world's most biodiverse rainforests to tap into surging demand (Myers et al., 2000). The effects of the price spike have been particularly egregious for smallholders, with sharp increases in vanilla-related theft and violence (Wexler, 2017). Further, the current high prices and declining overall quality of Madagascar vanilla have caused many larger operators to drop their Fairtrade and organic certification programmes. These operators remark that the increase in smallholder 'power' both to command high prices and to sell early have made sustainability programmes less effective and economically unviable.

Our results reveal that there has indeed been an overall increase in smallholders' power during the recent price spike in vanilla. Yet, this increase in power has not necessarily translated into an unmitigated increase in sustainability across the three dimensions - environmental, social and economic. Rather, we see an inverse relationship in some respects, as economic gains made from the price spike dramatically decrease vanilla crop quality and village-level security. While vanilla presents a unique opportunity to examine the often less-measured relationship between power and sustainability for commodity-led development, similar challenges remain with many other important global commodities. In our conclusion, we discuss the novelty, limitations and broader applications of access mapping, not only for vanilla, but also for sustainability efforts in associated highvalue agricultural commodities.

\section{Crossing disciplinary boundaries to address global sustainability}

The purpose of this article is to expand disciplinary boundaries and communicate integrated elements of the social sciences and humanities to wider audiences in order to address global challenges and drive social change (Hrynaszkiewicz and Acuto, 2015). Drawing on the strengths of its design, the work uses information and data visualisation to communicate diversity in the way market actors, and beyond, understand and measure changes in power and access in global commodity chains (Escobar, 2018). This addresses recent calls highlighting the importance of interdisciplinary sciences to address growing global challenges (Hulme, 2011). Such needed dialogue, Castree et al. (2014) suggest, is vital to 'engender plural representations of Earth's present and future that are reflective of divergent human values and aspirations'.

For instance, our access mapping model (see Fig. 1) uses integrated data visualisation to demonstrate how power changes over different periods of low and high price points and how smallholders experience this change. We build the commodity chain from the smallholders' perspective. This approach is vastly different from current firm-led sustainability models that rely principally on two 'top-down' approaches: sustainable supplychain management (SSCM) and global value-chains (GVC) (Porter, 1990). SSCM is a model used to streamline production through new information and communications technology, while building resilience and decreasing risk by securitising productive assets, including vital raw materials and human capital. GVC goes a step further to analyse potential opportunities for source countries to 'capture the gains' of commodity production through technological upgrading at the national or regional scale (Fearne et al., 2012). These two sustainability models are ideal for lead 


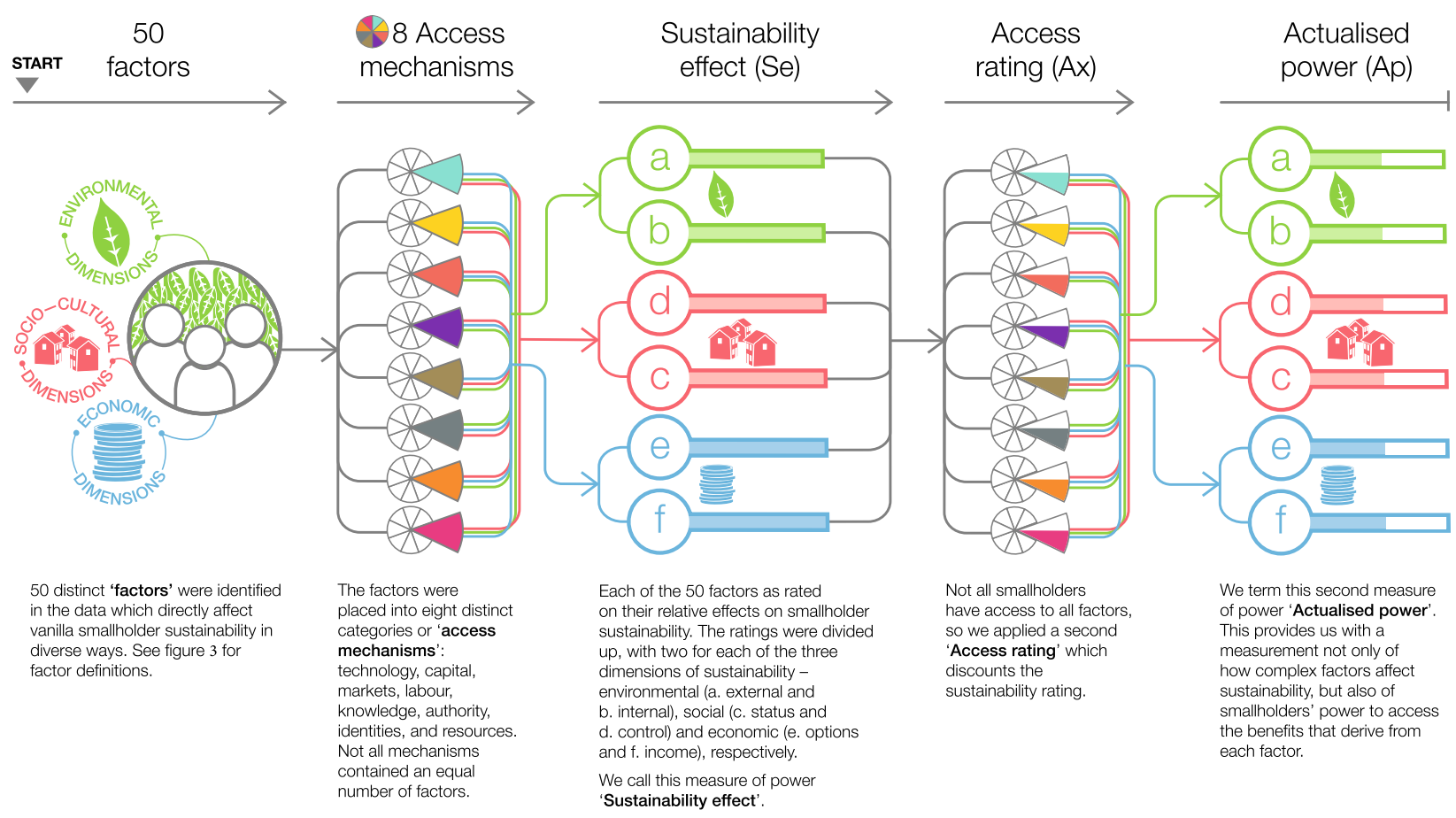

Fig. 1 Access mapping model. The model provides a means for quantifying the sustainability of vanilla production from the perspective of changes in smallholders' power to capture benefits from resource commercialisaton

firms to 'exercise control and influence market-relationships', yet are much less effective in highlighting asymmetrical power relations that exist between actors and socio-economic and ecological complexity and change (Gibbon and Ponte, 2005, p. 81). This absence is particularly astute in periods of price volatility when smallholders find themselves having to cope with rapid price fluctuations and crisis.

Our approach to visualising smallholder commodity relationships builds from 'counter-mapping' and 'participatory mapping' traditions within social sciences that adopt a bottom-up rather than a top-down approach to creating visual maps (Peluso, 1995). Social scientists have called for integrating multiple mapping methodologies to better 'understand the spatial organisation of local resource use and management as produced through social relations and contingent on changing social, political, economic and environmental processes' (Roth, 2007, p. 58). Following this, our access mapping methods and visualisations of commodity relationships account for dynamic social, economic, ecological and political relationships, taken across space and time.

Our visualisations of ethnographic data bring legibility and comprehension, and provide a metaphoric, visible form through which to make sense of complex and dynamic sustainability models (Stirling, 2010). For us, this is not merely a case of illustrating text. Rather, the visualisation enhances the legibility of the text (Tufte et al., 1998). Communicating the model visually enables its assimilation into existing practices and knowledge sets, opening up novel reflection through prototypical iterations, and deepening our own understanding of the model in both text and image (Dewey, 1934; Schön, 1983).

\section{Study design}

We conducted semi-structured interviews and socio-economic surveys with smallholder farmers in Madagascar in 2017 (during the 'boom' vanilla market) in the areas of Antalaha $(n=295)$ and Mananara Nord $(n=185)$. Surveys and interviews were held in multiple village sites and included a range of sustainability-related questions concerning crop security, production and trade.
Questions asked to smallholders were specifically in relation to the current vanilla price spike (measured in 2017) and in comparison to the 'bust' period just ten years previously (measured in 2007) (see Fig. 2 for examples of key quotes from smallholders).

We then coded the survey and interview data using a grounded-theory inductive process allowing smallholders' responses to guide the analysis. Through the coded text, we identified 50 distinct 'factors' which directly affect vanilla smallholder sustainability (see Fig. 3 for factor definitions).

The factors placed into eight categories or 'access mechanisms', which Ribot and Peluso (2003) define as the 'means, process and relations' which facilitate the capture of benefits from resource commercialisation (Ribot and Peluso, 2003). These eight mechanisms are technology, capital, markets, labour, knowledge, authority, identities and resources. Collectively, they clarify the complex relationship between power-one's ability to access benefits-and the three dimensions of sustainability, including environmental, economic, and social. Not all mechanisms contained an equal number of factors, reflecting the different weights of the mechanisms and their contribution to an aggregated measure of change in power. Numeric values were not included to our models in order to avoid errors in both cross-comparison of changes in power across mechanisms-as noted, not all mechanisms are equal- and the simple deduction of complex power relations to numeric values.

We see the three dimensions of sustainability not as standalone or static, but relational and dynamic. We, therefore, gave each of the 50 factors six ratings based on their relative effects on smallholder sustainability, including smallholders' power to capture benefits (see Fig. 3, also Supplemental Information section). The ratings ranged from a high of 4 (very positive effect for benefit capture) to a low of 0 (very negative effect for benefit capture) and were divided up, with two for each of the three dimensions of sustainability-environmental (a. external and b. internal), social (c. status and d. control) and economic (d. options and e. income), respectively. We call this measure the 'Sustainability effect' (Se). Critically, however, not all smallholders have 

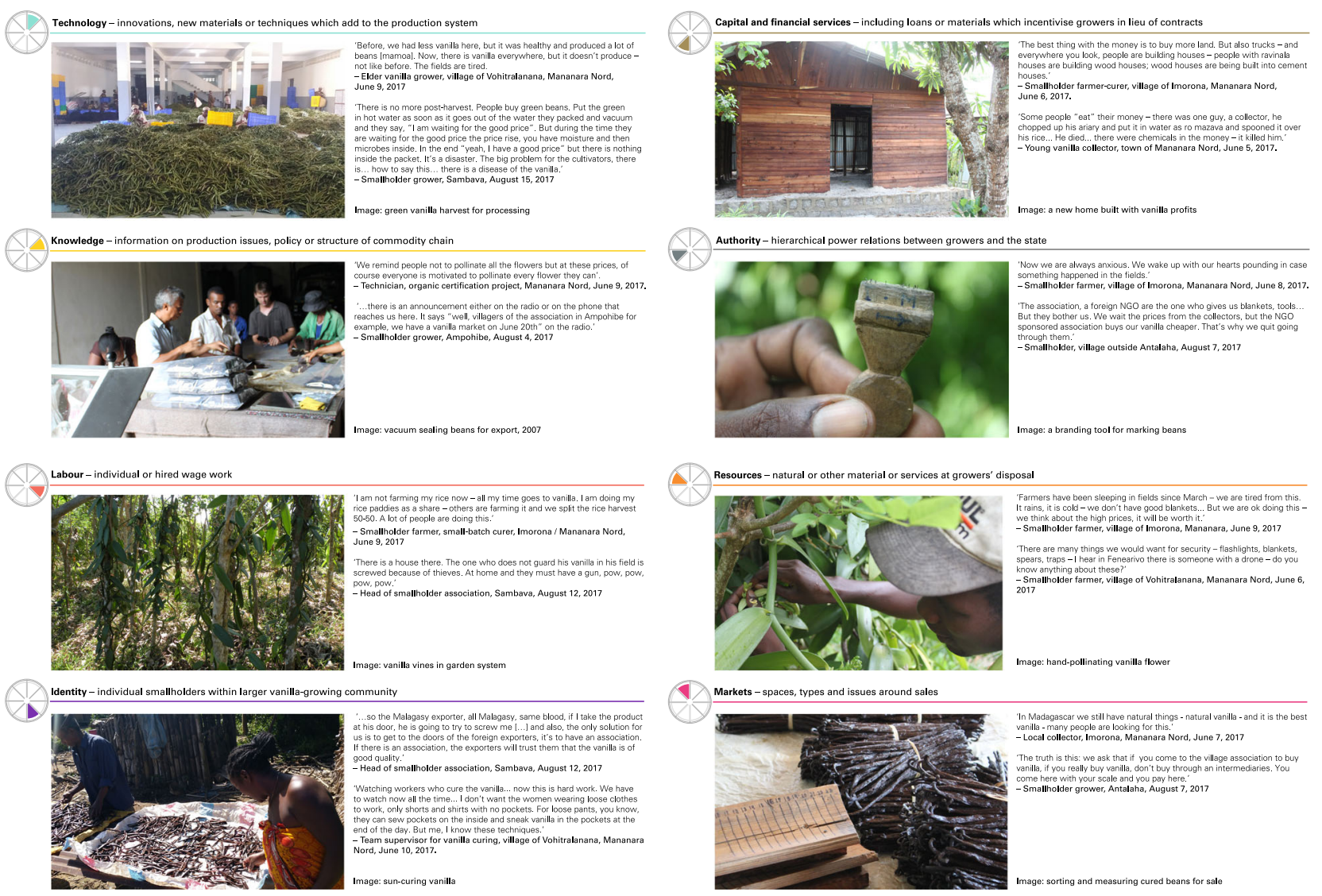

Fig. 2 Key quotes from smallholder. As shown below, some of these quotes reflect effects on sustainability, thereby demonstrating the complexity in the actual changes in smallholder power
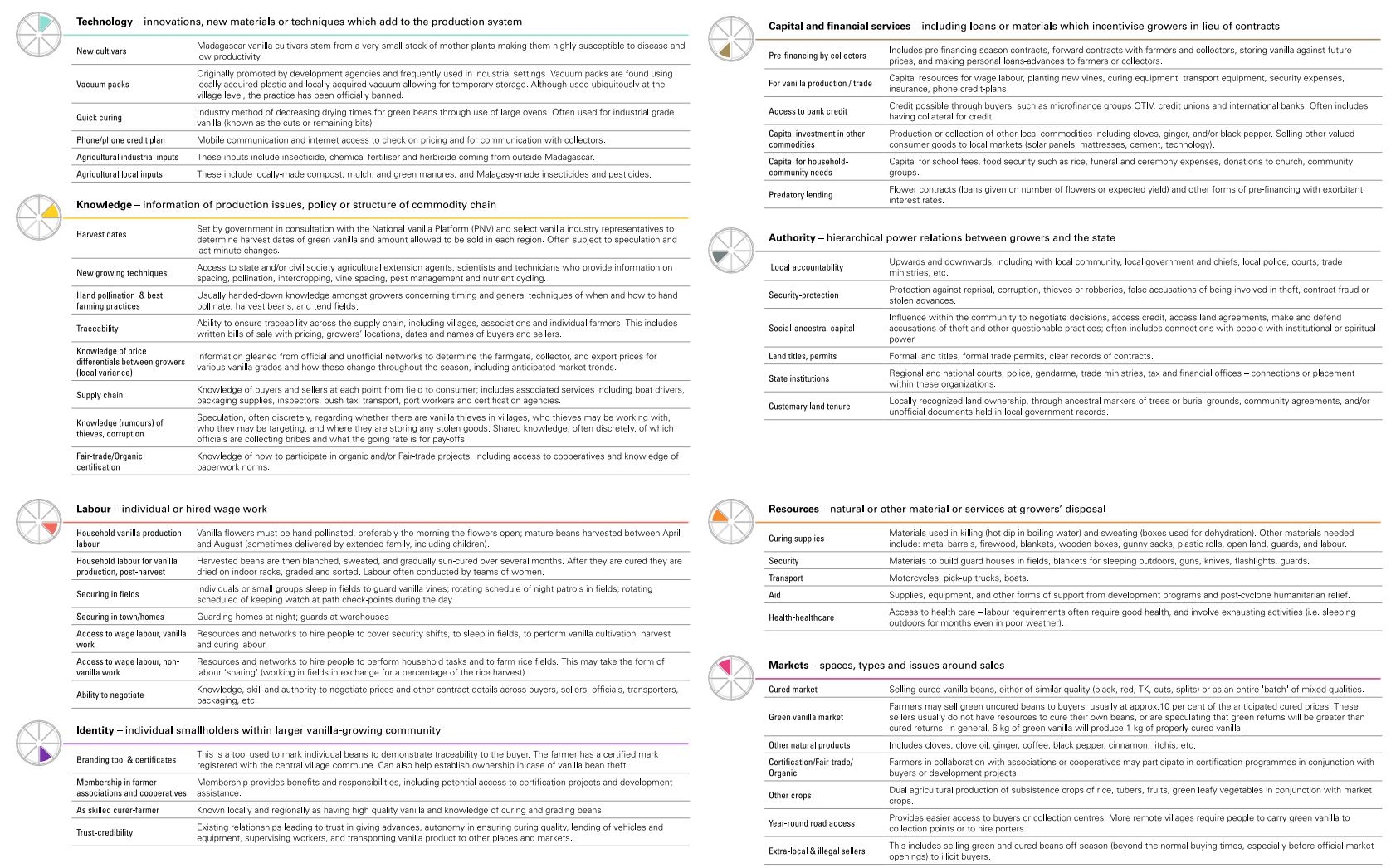

Fig. 3 Vanilla access mapping factor definitions. Fifty distinct 'factors' were identified in the data, which directly affect vanilla smallholder sustainability in diverse ways 


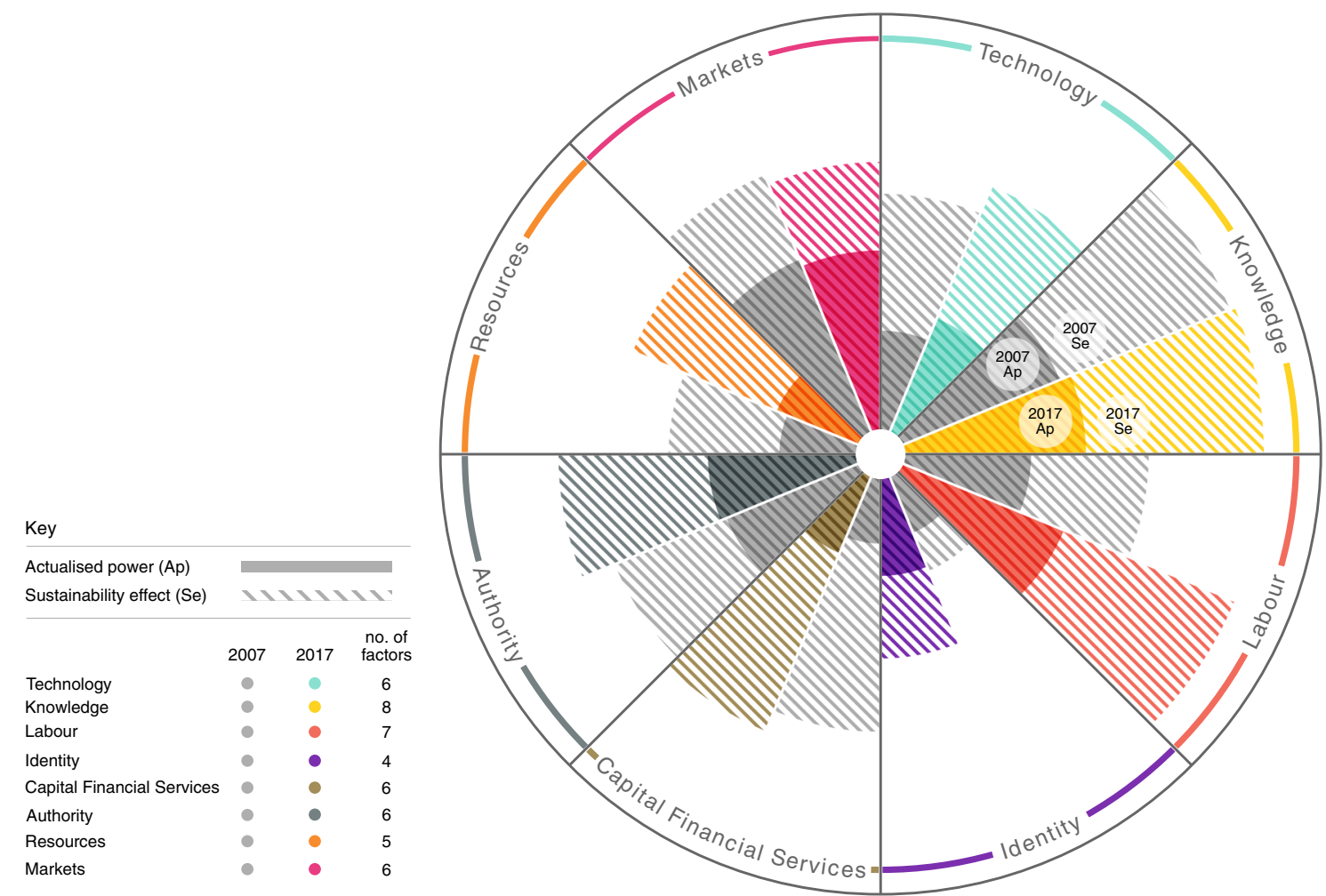

Fig. 4 Access mapping changes in smallholders' power at high (2007) and low (2017) price points. This figure is an access map showing the difference measured between smallholders' Sustainability effects ( $\mathrm{Se}$ ) and Actualised power (Ap). Se is a measure of changes in power that assumes smallholders have access to all factors that inform this model. It is visualised as cross-hatched sections. Ap represents the factors accessed by smallholders. It is visualised as a solid colour. Smallholders' power is divided into eight mechanisms through which they can access benefits from growing and selling vanilla at high and low price points in 2007 and 2017, respectively. Measures are visualised in either grey (2007) or bright colour hues (2017)

access to all factors-some are circumstantial, others are actively pursued or avoided-so we applied a second, 'Access' rating (Ax), on a numeric scale from 0.2 (no access) to 1 (very accessible), which discounts the sustainability rating above according to smallholders' ability to access the factor. This second measure we term 'Actualised power' (Ap). This provides us with an understanding not only of how complex factors affect sustainability, but also of smallholders' power to access the benefits that derive from each factor (see Fig. 1 for illustration of the model). We used linear weighted Cohen's Kappa (Kw) analysis to verify differences between the ratings. Visualised changes across low and high price points for both Se and Ap were populated into polar grids by mechanism, subtotal and by each individual factor (Figs. 4-6, respectively; see Supplemental Information for further details).

A clarifying note on power. Our working definition of power closely follows Ribot and Peluso's (2003) original conceptualisation in their seminal publication, 'theories of access.' Ribot and Peluso place power in very close relation to 'access' or what they see as one's 'ability to benefit from things' (2003, p. 155, emphasis added). They define power as, '...first, the capacity of some actors to affect practices and ideas of others...' and also, '...power as emergent from, but not always attached to, people'. Drawing on Foucault (1978), Ribot and Peluso reflect, '...that power is inherent in certain kinds of relationships and can emerge from or flow through the intended and unintended consequences or effects of social relationships. Disciplining institutions and practices can cause people to act in certain ways without any apparent coercion' (ibid, 2003 p. 155, see also Svarstad et al., 2018).

We also focus our 'attention to a wider range of social relationships', which are mobilised in both discursive and material forms that 'can constrain or enable people to benefit from resources' (Ribot and Peluso, 2003, p. 154). In our study, we demonstrate that there are multiple and overlapping access 'factors', which may affect, or be affected by, ones' ability to benefit from the rise in commodity prices (cf. Sen, 1995). We measure how, through the gaining or losing of access to things (e.g., new varieties or vacuum-sealing), power is generated or lost, and consider how this change in power subsequently mediates the ability to navigate material constraints and relations of production (e.g., vanilla needs to mature on the vine and therefore is vulnerable to theft). We also take care to position smallholders' access within broader structural constraints, including the historical, political and economic dimensions of market volatility, smallholder marginality and cultural identity, to name a few (West, 2012; Sen, 2017).

We do appreciate that there are significant differences in the way power is conceptualised, and thereby analysed, and by no means do we have the space to review them all here (for some reviews on power and resource governance see: Lukes, 2005; West, 2006; Ahlborg and Nightingale, 2012, 2018; Cavanagh, 2018; Svarstad et al., 2018). However, it is extremely important to identify how and where power is applied, source(s) of that power, and the consequences. We understand that social relationships are multiple, ranging across scales, from global to local (Neumann, 2009; Rangan and Kull, 2009). Power emanates from state (Sikor and Lund, 2009; Meehan, 2014; Harris, 2017; Asiyanbi, 2016) and non-state institutions (Ferguson, 1990; Hart, 2001; Bebbington et al., 2008; Büscher, 2010). Power is observed by some to be manifested through the disciplinary power of these institutions (Fletcher, 2010; Cavanagh, 2018) in the form of discourse (Escobar, 1994), policy (Goldman, 2008), knowledge production 


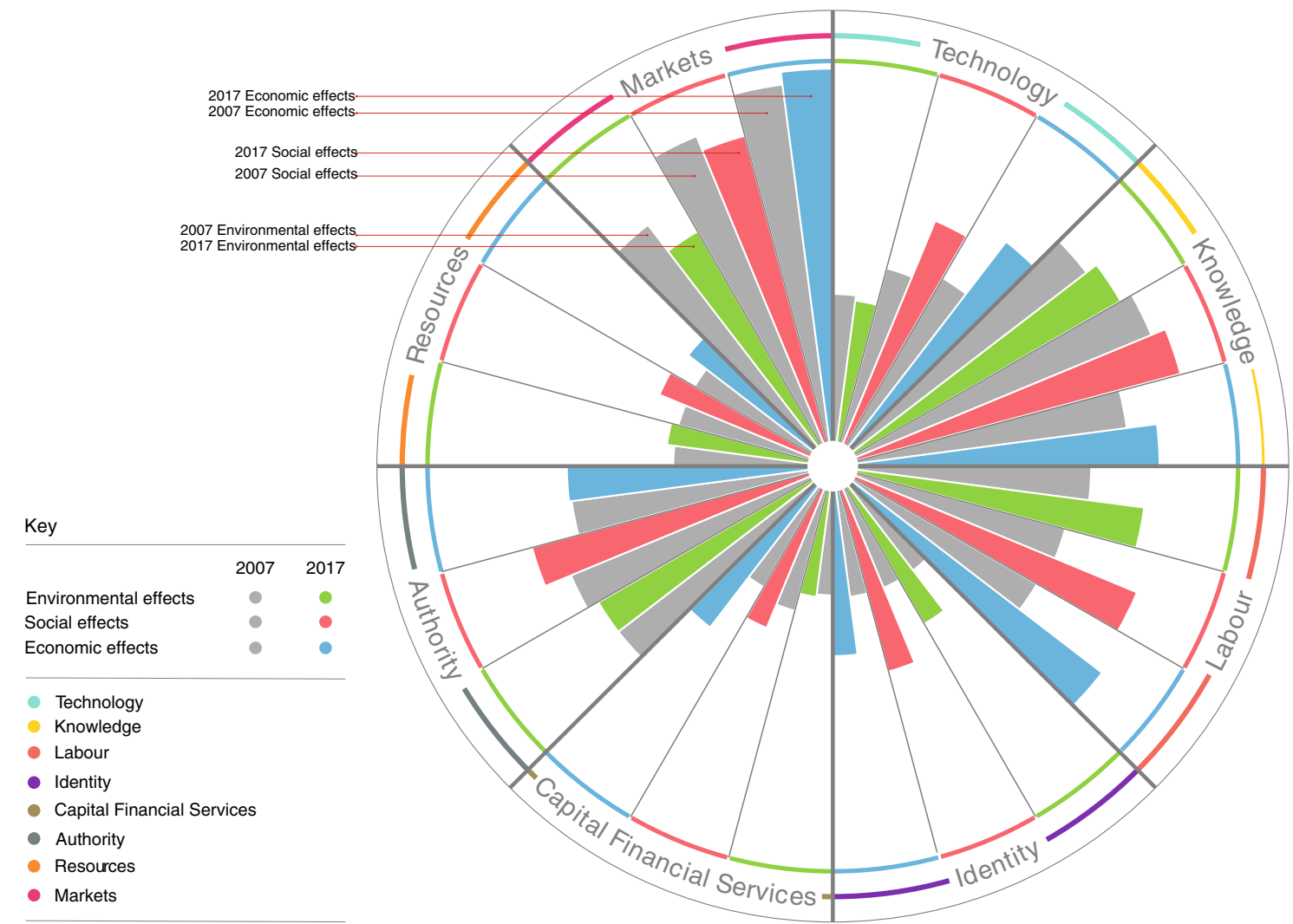

Fig. 5 Effects of changes in smallholders' power by mechanism subtotals on environmental, social and economic sustainability. This figure is an access map showing the effects of changes in smallholders' power on each of the three dimensions of sustainability. The ratings of each mechanism subtotal from the sustainability matrix for the environmental (a external and $\mathbf{b}$ internal), social (c status and $\mathbf{d}$ control), and economic (e options and $\mathbf{f}$ income) dimension, are visualised, respectively

(Goldman et al., 2011) and scientific research (Forsyth, 2004; Robbins, 2004; Neimark et al., 2019). Materiality, such as characteristics of the commodity (Bakker and Bridge, 2006), mediate power and social relations. Many also describe power through differences in class (Peet, 1998), gender (Schroeder, 1999; Nightingale, 2006; Elmhirst, 2011), race (Pulido, 2015), sexuality (Butler, 1993; Gandy, 2012), identity (Sundberg, 2004; Ojeda, 2012) and violence perpetrated by regional elites (Peluso, 1992).

We are in agreement with Svarstad et al., (2018, p. 355), that defining power through a structural lens may be too 'rigid' reifying top-down 'hierarchies of power', and therefore some have found different conceptualisations helpful, such as 'networks' (Robbins, 2004; Rocheleau, 2008), 'webs' or 'bundles' (Ribot and Peluso, 2003) or 'assemblages' (Li, 1999; Goldman et al., 2011). We recognise that this overly structural, class-based way of seeing power often dominates discussions, leaving out many other ways that some may see and define power. These are mainly through more constructivist elements of 'cultural hegemony' (Gramsci, 1982), which are non-class-based and take on more radical approaches of resistance (Laclau and Mouffe, 2001; Watts and Peet, 2004). Recent work on decolonial perspectives recognise the power of indigenous knowledge and labour that informs and sustains 'Euro-Western scholarship, activism and socio-political discourse' (Todd, 2016, p. 4). We therefore encourage those who apply this access map to measure and visualise power to carefully explore such varied and diverse conceptions and build off others forging vital links between humanities, design and social sciences (Escobar, 2018). We feel such conceptualisations will only help in deepening understandings of the multiple, layered and dynamic complexities of power in and around commodity relationships, particularly from a smallholder perspective.

\section{Results}

Visualising changes to smallholders' power. Our results show that smallholders held more overall power to access benefits during the recent price spike. This increase in power is reflected across seven of the eight different mechanisms that we measured (Figs. 4-6). As illustrated by Fig. 4, not all mechanisms had an equal relational influence on this overall increase in smallholder power. Such differences suggest that 'power' is not a homogenous variable for farmers who participate in commodity systems, but rather represents complex relationships that vary with changing economic conditions.

The category of labour showed a significant relational change for farmer power, meaning that the ability to access labour had a relatively greater effect on overall farmer power during the boom market. We attribute much of this effect to the added labour needed for security in homes and vanilla fields, as well as the relative advantage of hiring wage-labourers for household and other agricultural tasks, freeing up farmers to invest more time in the lucrative vanilla market.

As with labour, the category of authority exhibited a marked influence on increasing smallholders' power during the boom market. With increased security risks, people's ability to access courts, police and local authorities became an increasingly important form of protection against theft and fraud. In comparison, the authority of farmers to gain and maintain their formal and customary land tenure remained important in both low and high price points. This is not surprising, as during periods of volatility and insecurity land tenure acts as an environmental, social and economic 'security blanket' (Barrows and Roth, 1990).

For technology, access to low-input vacuum-pack sealers and industrial quick-curing machines also notably increased 


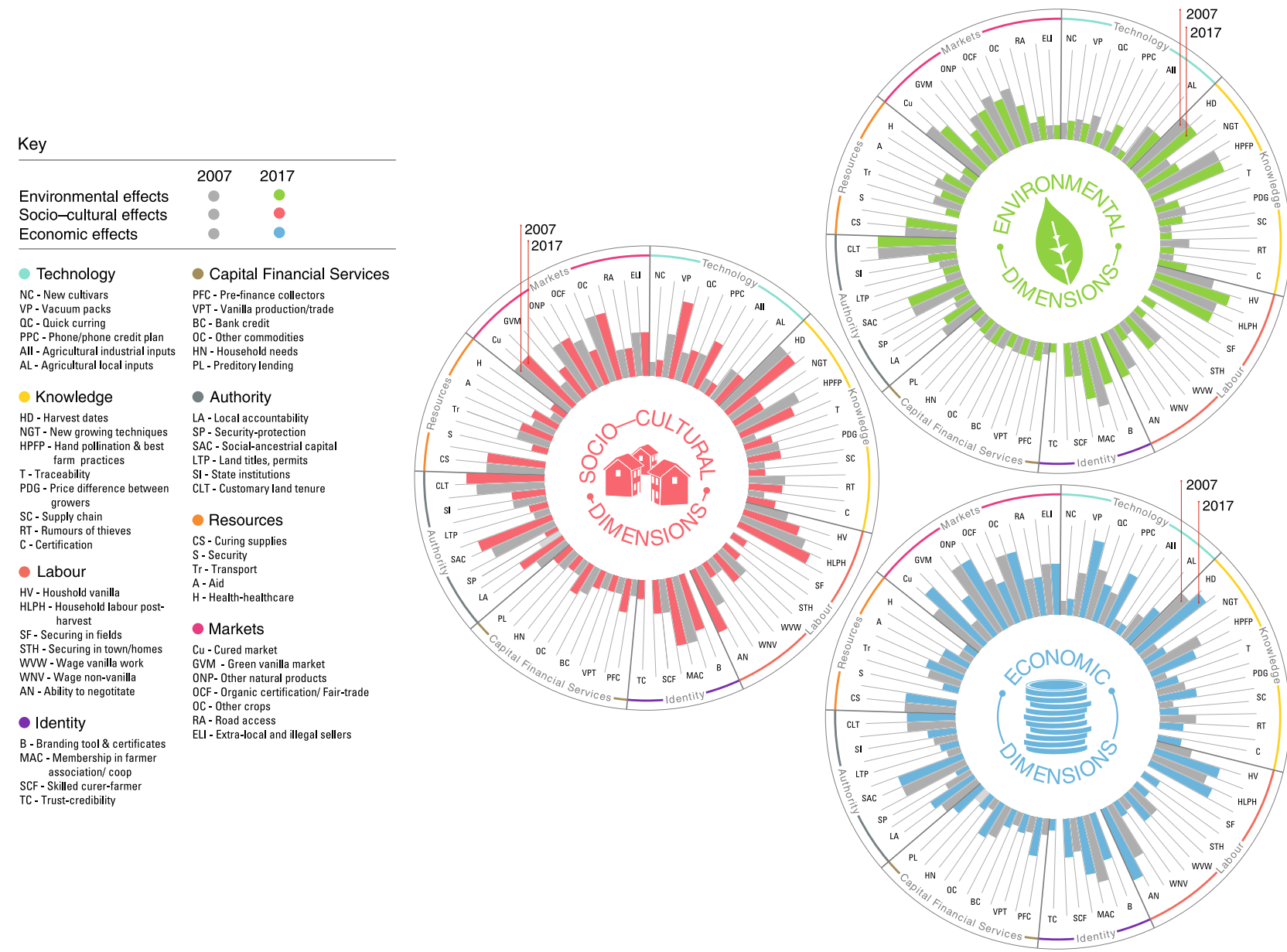

Fig. 6 Effects of changes in smallholders' power by individual factors on environmental, social and economic sustainability. This figure is an access map showing the effects of changes in smallholders' power on each of the three dimensions of sustainability. The ratings totals of each individual factor from the sustainability matrix for the environmental (a external and $\mathbf{b}$ internal), social (c status and $\mathbf{d}$ control), and economic (e options and $\mathbf{f}$ income) dimension are visualised, respectively

smallholder power. Once promoted during the low price points by development agencies, vacuum-packed vanilla is now prevalent in the vanilla market. By vacuum-sealing vanilla beans for long-term storage, farmers gain the ability to 'play the market' and increase their selling power - not having to sell to the first buyer and thereby being able to negotiate a better price. However with prices extremely high and theft ramped, many farmers and collectors are still sealing their vanilla before it is properly dried and cured, resulting in a large impact on vanilla quality. Consequently, smallholder adoption of vacuum packs has been one of the biggest points of contention with exporters, as the resultant decrease in quality translates into an overall loss in the value of vanilla beans on the international market (Hachman, 2017).

Although the results for knowledge did not markedly change over the period from 2007 to 2017, this category remains important in terms of its relationship to smallholders' power in both bust and boom markets. It includes smallholders' knowledge of official harvest dates, of hand pollination and farming/curing practices, and of price differentials at various nodes in the commodity chain. Some factors saw a decrease in relational importance during the boom market up to 2017, including smallholder knowledge of certification projects.

Similar to knowledge, the category of capital remained important for maintaining smallholder power in both bust and boom markets. Yet, the advantages for farmers with access to greater capital resources through loans and cash in hand were significantly higher during the price spike, when farmers had higher capital requirements for security, wage-labour, and smallscale vanilla purchasing needs. A very significant negative factor on smallholder power in both boom and bust markets is the practice of predatory lending, which often leads households into further debt-a harmful economic cycle also seen with other commodity relationships, including cotton (Stone, 2002) and coffee (Wilson, 2010).

For resources, having access to curing supplies to process raw vanilla beans remained correlated with increased farmer power in both high and low markets. Cured beans command a higher price on the market, and can be stored for longer than raw beans, giving farmers more power in timing their vanilla sales. As security becomes a concern in the boom market, farmer resources including weapons for protection, blankets for sleeping in the fields, and materials to build guard posts become vitally important.

The category of identity had a relationally positive impact on smallholder power in 2017, especially for those individuals considered trustworthy and skilled farmers. In the heightened tensions of the boom market, collectors and traders increasingly look to work with farmers with an established 'track record'. The importance of trust and social reciprocity speaks more broadly to the diffuse nature of power and value in commodity production, which connects to individual relationships between farmers and between farmers and collectors (Fafchamps and Minten, 2002). 
Finally, the category of markets was the only mechanism for which farmers' power decreased between the two periods, indicating that the advantages of having market connections become less of a 'power' factor for smallholders when vanilla prices are highest. High prices coupled with low supply mean farmers do not need to seek out buyers, as buyers are motivated to track down farmers with vanilla to sell. The overall decrease for the market category can also be attributed to the collapse of both organic and Fairtrade certification programmes. This category also illustrates that many smallholders are not diversifying their agricultural and economic efforts during the boom market, as the majority of their labour is devoted to growing and securing vanilla. Hence, commodity sustainability efforts, which focus exclusively on price, are problematic: when commodity prices drop, farmers may be left without diversified agricultural and economic resources (Osterhoudt, 2017).

The eight categories and their constituent factors had differing influences on the three dimensions of vanilla sustainability, as illustrated in Figs. 4 and 5. Our results show the multiple factors that determine the uneven and variable sustainability outcomes within the vanilla market from a smallholder perspective. As with smallholder power relationships, depending on the case, factors could have either complementary or contradictory sustainability outcomes.

For example, the case of vacuum-sealing technology illustrates how one factor can have competing sustainability implications: while vacuum-sealing beans increases the economic sustainability of smallholder farmers in the current market, it also decreases their environmental sustainability in relation to overall vanilla quality (Figs. 5 and 6). Further, the decreased quality of Madagascar vanilla is causing some buyers to look for other sources; such a shift to other countries would pose an economic sustainability challenge for smallholder farmers in coming years. As another example of competing sustainability effects, the increased practice of smallholders pollinating all of their vanilla flowers during the boom market increased household economic autonomy but decreased the environmental health of vanilla vines.

\section{Discussion: linking power and access}

Our results illustrate that the boom market in vanilla has led to an overall increase in smallholder power across environmental, social and economic dimensions. Power in this sense encompasses both material and social realms, including the ability to influence interpersonal relationships and dynamics in informal, everyday contexts (Foucault, 1991). Yet this moment of empowerment, while welcomed by farmers in the short term, may be leading to practices that will raise new sustainability challenges to vanilla farmers' livelihoods in the future.

For example, those in the vanilla industry with the necessary capital, power, mobility and connections are once again looking to other countries and other products to replace Madagascar vanilla, which has reached price points and quality markers unsustainable from the industry's perspective (Kenward, 2017). Further, the current dynamics seem poised to set up another vanilla 'bust' market. If realised, both of these developments would have negative implications for Malagasy vanilla farmers, many of whom are already on the margins of household food security.

One implication of our results is that sustainability initiatives working with producers should not simply focus on high prices, but rather take into account the complex, relational effects of power, change and uncertainty within local communities. In the case of vanilla, the current high prices should not prompt firms to abandon their commitments to community sustainability programmes as no longer relevant, but rather to shift their programmes to address the unique concerns brought about by the boom market (such as vanilla security and quality) that will support the sustained success of Madagascar's vanilla producers and forest environments over the long-term.

In order to understand the unique challenges of both boom and bust markets, sustainability models need to account for the complex and changing relationships between power, access and markets across the entire supply-chain, including at the smallholder level. Yet, firms involved in high-value commodity markets are increasingly integrating sustainability models into their business operations that largely adopt static, equilibrium-based representations of commodity relations. These models assume baseline 'generalised' socio-economic and environmental conditions within sites of production. Because of these assumptions, such models have proven less successful at achieving sustainability objectives in times of acute change and uncertainty.

Yet, smallholder farmers who produce high-value commodities for international markets continuously face a high degree of economic, social and environmental change and uncertainty. For example, for vanilla farmers in Madagascar, price points are rarely, if ever, at an 'average' level and instead fluctuate between extreme market highs and prolonged times of market depression. Environmental conditions in tropical ecosystems are seldom stable, with frequent cyclones, drought, pests and fungal diseases, and other challenges related to climate change (Morton, 2007). Social and political structures that govern vanilla production and trade are also highly unpredictable and liable to sudden shifts (Innes, 2010). In the face of such uncertainty, smallholder farmers have developed complex, dynamic approaches to vanilla production and trade that regard change and uncertainty as intrinsic to commodity systems (Dove and Kammen, 1997).

Taking a cue from the smallholders themselves, we have proposed a model that takes a farmer-based approach to commodity relationships, and that regards change and uncertainty as constitutive of-and not external to-linked historical, economic, social and environmental systems (Nagendra, 2018). This model additionally unpacks the 'black box' of smallholder power within commodity-chain relationships. For example, it notes the complex array of variables that influence farmers' ability to access the advantages of the vanilla trade and to avoid the disadvantages of the market, across both high and low price points. Understanding the diverse mechanisms of smallholder power across material, economic, social and cultural contexts is necessary to develop a more realistic understanding of how these village-level dynamics affect-and are affected by-firm-led sustainability programmes.

\section{Looking ahead: applications for sustainability}

We argue that mainstream models for sustainable commodity production flatten the complex, recursive relationships of power, access, uncertainty and change at all points of supply-chain relationships. These simplified models lead to top-down approaches to commodity-chain management. They often support interventions that prove to be counter-productive, by narrowing the options along the chain instead of opening them up to adapt to shifting environmental and economic conditions, and to support the social agency and strategic positioning of actors along the commodity network. Further, sustainable initiatives often identify high price points as a key driver of sustainability. Yet, while high prices to farmers are indeed an important component of sustainable commodity chains, they are not sufficient to foster social, economic and environmental sustainability (Steneck et al., 2011).

Increasingly, researchers are using complex socio-economic systems approaches and models to address pressing environmental challenges, such as the effects of climate change (Sterling et al., 2017), biodiversity conservation (Evans et al., 2017) and deforestation (Brun et al., 2015). However, these forms of 
ecological and social complexity have been applied less to the development of tools for envisioning sustainable commodity chains, mainly because of the drive to 'clean-up' exogenous factors and bring about efficient production. We illustrate that a smallholder access model to commodity chains can account for a wider range of relational economic, social, cultural and environmental factors linked in historically shifting commodity relationships. The resulting complexity defies simple relationships of causation between various aspects of the supply-chain, but situates them within the 'messier' realities of networked, relational and non-equilibrium systems (Zimmerer, 1994).

From an applied perspective, working from access-based models opens up sustainability interventions for government agencies, civil society and industry across new realms of smallholder outreach. These go beyond income-generation initiatives, including complex variables which range from security to transparent land governance. Our results support the design of sustainability approaches to commodity relationships that increase the power, access and options for smallholder farmers (Borras et al., 2011). These are deliberately flexible and adaptive to change and uncertainty at both high and low price points (Alcorn, 1989).

We do recognise, however, that like most models there are limitations to the access mapping approach we put forward. First, while certain factors foster smallholder empowerment, these factors are not universally accessible to all members of a community (Li, 2014). We recognise that smallholders vary widely, participating in market relations according to their different social and structural histories; they have unequal access to resources and benefits (Agrawal and Gibson, 1999). In this vein, we understand that this is just a snapshot over two price points and that accessibility to resources including capital, land, improved growing material, market advances and transportation differ in high and low markets, and indeed even within differing months in any one given season. Finally, we recognise the complexities of considering power as an analytical category, as individuals exercise power across a range of material and cultural forms.

A second limitation is that our presentation only shows the access map of one, albeit important, node of the commodity chain -the smallholder. Further studies could expand the access map by looking both at horizontal inequalities that exist within smallholder groupings through gender, race, class and other structural formulations (Park and White, 2017) and at smallholders as compared to other nodes such as collectors or exporters (West, 2012).

Overall, this approach will foster flexibility to work with, instead of against, existing social and cultural relationships connected with high-value commodity chains (Straka et al., 2018). It acknowledges that for vanilla-like many high-value crops cultivated by smallholders throughout the globe-there is no 'normal' market. Further, many of these crops, including coffee, palm oil and cocoa, have also experienced unprecedented price spikes in recent years. The significance of such models is increasingly pressing, with many forest-based and high-value commodities facing similar dynamics of compounded social, economic and environmental uncertainty and change across the globe.

\section{Data availability}

The full qualitative datasets generated during and/or analysed during the current study are not publicly available at this time due to the ongoing and sensitive nature of the ethnographic material. The quantitative data table generated are fully available at: https:// doi.org/10.17635/lancaster/researchdata/229.

Received: 1 July 2018 Accepted: 15 November 2018

Published online: 15 January 2019

\section{References}

Abdulsamad A, Frederick S, Guinn A, Gereffi G (2015) Pro-poor development and power asymmetries in global value chains. [online] Center on Globalization, Governance and Competitiveness, Duke University, Durham, NC, Available at https://gvcc.duke.edu/wp-content/uploads/Pro-PoorDevelopment_and_PowerAsymmetries_inGlobalValueChains_Final.pdf

Agrawal A, Gibson CC (1999) Enchantment and disenchantment: the role of community in natural resource conservation. World Dev 27:629-649

Ahlborg H, Nightingale AJ (2012) Mismatch between scales of knowledge in Nepalese forestry: epistemology, power, and policy implications. Ecol Soc 17 (4): 16

Ahlborg H, Nightingale AJ (2018) Theorizing power in political ecology: the where of power in resource governance projects. J Political Ecol 25:381-401

Alcorn JB (1989) Process as resource: the traditional agricultural ideology of Bora and Huastec resource management and its implications for research. Adv Econ Bot 7:63-77

Asiyanbi AP (2016) Beyond utopia and a 'power-full'state: a reply to $\mathrm{N}$ uesiri. Geogr J 182(1):104-106

Bakker K, Bridge G (2006) Material worlds? Resource geographies and the matter of nature. Progress Human Geogr 30(1):5-27

Barrows R, Roth M (1990) Land tenure and investment in African agriculture: Theory and evidence. J Mod Afr Stud 28:265-297

Bebbington AJ, Hickey S, Mitlin D (2008) Can NGOs make a difference?: The challenge of development alternatives. Zed Books: London and New York

Borras Jr SM, Hall R, Scoones I, White B, Wolford W (2011) Towards a better understanding of global land grabbing: An editorial introduction. J Peasant Stud 38:209-216

Brondízio ES, Safar CA, Siqueira AD (2002) The urban market of açaí fruit (Euterpe oleracea Mart.) and rural land use change: ethnographic insights into the role of price and land tenure constraining agricultural choices in the Amazon estuary. Urban Ecosyst 6:67-97

Brun C et al. (2015) Analysis of deforestation and protected area effectiveness in Indonesia: A comparison of Bayesian spatial models. Glob Environ Change 31:285-295

Büscher B (2010) Anti-politics as political strategy: Neoliberalism and transfrontier conservation in southern Africa. Dev Change 41(1):29-51

Butler J (1993) Bodies that matter: On the discursive limits of "sex". Routledge, New York, NY and London

Castree $\mathrm{N}$ et al. (2014) Changing the intellectual climate. Nat Clim Change 4.9:763

Cavanagh CJ (2018) Political ecologies of biopower: diversity, debates, and new frontiers of inquiry. J Political Ecol 25(1):402-425

Clough Y, Faust H, Tscharntke T (2009) Cacao boom and bust: sustainability of agroforests and opportunities for biodiversity conservation. Conserv Lett 2:197-205

Dallas M, Ponte S, Sturgeon T (2017) A typology of power in global value chains (no 91). Working paper in business and politics [online]. Available at: http:// openarchive.cbs.dk/handle/10398/9503

Dewey J (1934) Art as Experience. Perigree, New York, NY

Dove M, Kammen D (1997) The epistemology of sustainable resource use: Managing forest products, swiddens, and high-yielding variety crops. Human Organ 56:91-101

Elmhirst R (2011) Introducing new feminist political ecologies. Geoforum 42:129-132

Escobar A (1994) Encountering development: The making and unmaking of the third world. Princeton University Press, New Jersey

Escobar A (2018) Designs for the pluriverse: Radical interdependence, autonomy, and the making of worlds. Duke University Press, Durham, NC

Evans MC, Davila F, Toomey A, Wyborn C (2017) Embrace complexity to improve conservation decision making. Nat Ecol Evol 1:1588

Fafchamps M, Minten B (2002) Returns to social network capital among traders. Oxf Econ Pap 54:173-206

Fearne A, Garcia Martinez M, Dent B (2012) Dimensions of sustainable value chains: implications for value chain analysis. Supply Chain Manag: Int J 17 (6):575-581

Ferguson J (1990) The anti-politics machine: 'Development', depoliticization and bureaucratic power in lesotho. CUP Archive, Cambridge

Fletcher R (2010) Neoliberal environmentality: towards a poststructuralist political ecology of the conservation debate. Conserv Soc 8(3):171-181

Forsyth T (2004) Critical political ecology: the politics of environmental science. Routledge, New York, NY and London

Foster K (2013) General mills commits to sustainably source 10 priority ingredients by 2020 . Press release 25 September 2013 [online]. Available at: https://www. generalmills.com/en/News/NewsReleases/Library/2013/September/ sourcing_10

Foucault M (1978) History of sexuality. Vol. 1: an introduction. Vintage, New York, NY 
Foucault M (1991) Governmentality. In: Burchell G, Gordon C and Miller P (eds) The foucault effect: Studies in governmentality. University of Chicago Press, pp. $87-104$

Gandy M (2012) Queer ecology: nature, sexuality, and heterotopic alliances. Environ Plan D: Soc Space 30(4):727-747

Gibbon P, Ponte S (2005) Trading down: Africa, value chains, and the global economy. Temple University Press, Philadelphia

Goldman M (2008) Imperial Nature: The world bank and struggles for social justice in the age of globalization. Yale University Press, New Haven

Goldman MJ, Nadasdy P, Turner MD (eds) (2011) Knowing Nature: Conversations at the Intersection of Political Ecology and Science Studies. University of Chicago Press

Gramsci A (1982) Selections from the prison books. Translation: Hoare Q and Nowell-Smith G. Lawrence and Wishart, London

Hachman A (2017) Vanilla market update November 2017. [online] Available at: http://www.austhachcanada.com/november-2017-english/

Harris LM (2017) Political ecologies of the state: Recent interventions and questions going forward. Political Geogr 58:90-92

Hart G (2001) Development critiques in the 1990s: Culs de sac and promising paths. Progress Human Geogr 25(4):649-658

Hrynaszkiewicz I, Acuto M (2015) Palgrave Communications-Connecting research in the humanities, social sciences and business. Palgrave Commun 1:14006

Hulme M (2011) Meet the humanities. Nat Clim Change 1(4):177

Innes JL (2010) Madagascar rosewood, illegal logging and the tropical timber trade. Madag Conserv \& Dev 1:6-10

Kenward E (2017) Crisis in the vanilla market [online] Food ingredients first. 17 October 2016. Available at: http://www.foodingredientsfirst.com/news/ special-report-crisis-in-the-vanilla-market.html

Laclau E, Mouffe C (2001) Hegemony and Socialist Strategy: Towards a Radical Democratic Politics. Verso Trade: New York and London.

Lambin EF et al. (2018) The role of supply-chain initiatives in reducing deforestation. Nat Clim Change 8:109-116

Laney R, Turner BL (2015) The persistence of self-provisioning among smallholder farmers in Northeast Madagascar. Human Ecol 43:811-826

Lee J, Gereffi G, Beauvais J (2012) Global value chains and agrifood standards: Challenges and possibilities for smallholders in developing countries. Proc Natl Acad Sci, USA 109:12326-12331

Li TM (1999) Compromising power: Development, culture, and rule in Indonesia. Cult Anthropol 14(3):295-322

Li TM (2014) Land's end: Capitalist relations on an indigenous frontier. Duke University Press, Durham, NC

Lukes S (2005) Power: A radical view. The original text with two major new chapters. Palgrave Macmillan, London

Meehan KM (2014) Tool-power: Water infrastructure as wellsprings of state power. Geoforum 57:215-224

Morton JF (2007) The impact of climate change on smallholder and subsistence agriculture. Proc Natl Acad Sci, USA 104:19680-19685

Mutersbaugh T (2002) The number is the beast: a political economy of organiccoffee certification and producer unionism. Environ Plan A 34:1165-1184

Myers N, Mittermeier RA, Mittermeier CG, Da Fonseca GA, Kent J (2000) Biodiversity hotspots for conservation priorities. Nature 403:853-858

Nagendra H (2018) The global south is rich in sustainability lessons that students deserve to hear. Nature 557:485-488

Neimark BD, Childs JR, Nightingale A, Cavanagh C, Sullivan S, Benjaminsen T, Batterbury S, Koot S, Harcourt W (2019) Speaking power to 'post-truth': critical political ecology and the new authoritarianism. Ann Assoc Am Geogr, https://doi.org/10.1080/24694452.2018.1547567

Neumann RP (2009) Political ecology: theorizing scale. Progress Human Geogr 33 (3):398-406

Newton P, Agrawal A, Wollenberg L (2013) Enhancing the sustainability of commodity supply chains in tropical forest and agricultural landscapes. Glob Environ Change 23:1761-1772

Nightingale A (2006) The nature of gender: work, gender, and environment. Environ Plan D: Soc Space 24(2):165-185

Ojeda D (2012) Green pretexts: Ecotourism, neoliberal conservation and land grabbing in Tayrona National Natural Park, Colombia. J Peasant Stud 39 (2):357-375

Osterhoudt SR (2017) Vanilla Landscapes: Meaning, memory, and the cultivation of place in Madagascar. New York Botanical Garden: New York

Paoli G (2015) Risky Business. Motivating Uptake and Implementation of Sustainability Standards in the Indonesian Palm Oil Sector. Center for International Forestry Research (CIFOR), Bogor, Indonesia

Park CMY, White B (2017) Gender and generation in Southeast Asian agrocommodity booms. J Peasant Stud 44:1103-1110

Peluso NL (1992) Rich forests, poor people: resource control and resistance in java. University of California Press

Peluso N (1995) Whose woods are these? Counter-mapping forest territories in Kalimantan, Indonesia. Antipode 27(4):383-406
Porter ME (1990) The competitive advantage of nations. Compét Intell Rev 1:14 Peet R (1998) Modern geographic thought. Wiley-Blackwell, New Jersey

Pulido L (2015) Geographies of race and ethnicity 1: White supremacy vs white privilege in environmental racism research. Progress Human Geogr 39 (6):809-817

Rangan H, Kull CA (2009) What makes ecology political?: rethinking scale in political ecology. Progress Human Geogr 33(1):28-45

Ribot JC, Peluso NL (2003) A theory of access. Rural Sociol 68:153-181

Rocheleau DE (2008) Political ecology in the key of policy: From chains of explanation to webs of relation. Geoforum 39(2):716-727

Robbins P (2004) Political ecology in political geography. Political Geogr 22:641-645

Roth R (2007) Two-dimensional maps in multi-dimensional worlds: A case of community-based mapping in Northern Thailand. Geoforum 38(1):49-59

Schön DA (1983) The reflective practitioner: How professionals think in action. Basic Books, New York, NY

Schroeder RA (1999) Shady practices: Agroforestry and gender politics in the Gambia. University of California Press

Sen A (1995) Gender inequality and theories of justice. In: Nussbaum MC and Glover J (eds) Women, culture and development: A study of human capabilities. Oxford University Press: Oxford, UK, pp. 259-273

Sen D (2017) Everyday sustainability: Gender justice and fair trade tea in Darjeeling. SUNY Press, Albany, NY

Sikor T, Lund C (2009) Access and property: a question of power and authority. Dev Change 40(1):1-22

Steneck RS et al. (2011) Creation of a gilded trap by the high economic value of the Maine lobster fishery. Conserv Biol 25:904-912

Sterling EJ et al. (2017) Biocultural approaches to well-being and sustainability indicators across scales. Nat Ecol Evol 1:1798

Stirling A (2010) Keep it complex. Nature 468(7327):1029

Stone GD (2002) Biotechnology and suicide in India. Anthropol News 43:5

Straka TM, Bal P, Corrigan C, Di Fonzo MM, Butt N (2018) Conservation leadership must account for cultural differences. J Nat Conserv 43:111-116

Sundberg J (2004) Identities in the making: conservation, gender and race in the Maya Biosphere Reserve, Guatemala. Gend, Place \& Cult 11(1):43-66

Svarstad H, Benjaminsen TA, Overå R (2018) Power theories in political ecology. J Political Ecol 25(1):350-363

Terazono (2017) Vanilla price reaches record high after Madagascar cyclone [online] FinancialTimes 24 April 2017. Available at: https://www.ft.com/ content/e0e2fc16-28db-11e7-bc4b-5528796fe35c?mhq5j=e1

Thorlakson T, de Zegher JF, Lambin EF (2018) Companies' contribution to sustainability through global supply chains. Proc Natl Acad Sci, USA 115 (9):2072-2077

Todd Z (2016) An indigenous feminist's take on the ontological turn: 'Ontology' is just another word for colonialism. J Hist Sociol 29(1):4-22

Tufte ER, McKay SR, Christian W, Matey JR (1998) Visual explanations: images and quantities, evidence and narrative. Comput Phys 12:146

Watts MJ (1993) Development I: power, knowledge, discursive practice. Progress Human Geogr 17(2):257-272

Watts M, Peet R (2004) Liberating political ecology. Lib Ecol: Environ, Dev, Social Mov 2:3-43

Weber M (1978) Economy and Society: An Outline of Interpretive Sociology. vol 1. University of California Press: Berkeley, CA

West P (2006) Conservation is our Government Now: The Politics of Ecology in Papua New Guinea. Duke University Press, Durham, NC

West P (2012) From Modern Production to Imagined Primitive: The Social World of Coffee from Papua New Guinea. Duke University Press, Durham, NC

Wexler A (2017) Your taste for fancy vanilla is creating world-wide havoc. Wall Street J. 15 December

Wilson BR (2010) Indebted to fair trade? Coffee and crisis in Nicaragua. Geoforum 41:84-92

Zimmerer KS (1994) Human geography and the "new ecology": The prospect and promise of integration. Ann Assoc Am Geogr 84:108-12

\section{Acknowledgements}

This research was made possible by generous support from the Arts and Humanities Research Council Grant - Leapfrog Project \#AH/M001296/1 (Alter) and The Creative Exchange Project \#AH/J005150/1 (Gradinar). Fieldwork was conducted with N8 AgriFood and Lancaster University Faculty of Science and Technology Impact Awards (Neimark), and a National Science Foundation, Senior Research Grant - Cultural Anthropology \#1729513 (Osterhoudt). We also want to thank our partners in Madagascar, Joseph Benitsiafantoka of the Central University of the SAVA region (CURSA), and Tim Healy of Aquaterre. We deeply want to thank a host of excellent scholars for their comments on earlier versions of this draft, including Jacob Phelps, Luke Parry, Peter Wynn, Nick Graham, Christina Hicks, Jos Barlow, and Eduardo Brondizio. Thanks also to Jonathan Ingram for superb editorial support and statistical analysis by Bryce Malton and Nadia Akers. 


\section{Additional information}

Supplementary information: The online version of this article (https://doi.org/10.1057/ s41599-018-0199-0) contains supplementary material, which is available to authorised users.

Competing interests: The authors declare no competing interests.

Reprints and permission information is available online at http://www.nature.com/ reprints

Publisher's note: Springer Nature remains neutral with regard to jurisdictional claims in published maps and institutional affiliations. (c) (i) Open Access This article is licensed under a Creative Commons Attribution 4.0 International License, which permits use, sharing, adaptation, distribution and reproduction in any medium or format, as long as you give appropriate credit to the original author(s) and the source, provide a link to the Creative Commons license, and indicate if changes were made. The images or other third party material in this article are included in the article's Creative Commons license, unless indicated otherwise in a credit line to the material. If material is not included in the article's Creative Commons license and your intended use is not permitted by statutory regulation or exceeds the permitted use, you will need to obtain permission directly from the copyright holder. To view a copy of this license, visit http://creativecommons.org/ licenses/by/4.0/.

(C) The Author(s) 2019 